\title{
Erythrocyte Age-Dependent Changes of Membrane Protein 4.1: Studies in Transient Erythroblastopenia ${ }^{1}$
}

\author{
YADDANAPUDI RAVINDRANATH, FREDERICK BROHN, AND ROBERT M. JOHNSON \\ Departments of Pediatrics, [Y.R., F.B.] and Biochemistry [R.M.J.], Wayne State Medical School, and Children's \\ Hospital of Michigan, Detroit, Michigan 48201
}

\begin{abstract}
In high resolution sodium dodecyl sulfategel electrophoresis, the red cell protein, band 4.1, separates into $a$ and $b$ forms, which are closely sequence related polypeptides. In membranes from patients with hemolytic anemia, the relative amount of band $4.1 \mathrm{~b}$ is increased, which has led to a suggestion that the relative proportion of these two 4.1 forms might be age dependent (Sauberman N, Fortier NL, Fairbanks GF, O'Connor RJ, Snyder LM 1979 Biochim Biophys Acta 556:292-313). We have measured the relative proportions of bands 4.1 $a$ and $b$ in the red cells of seven patients with transient erythroblastopenia of childhood. In this disease, temporary cessation of erythroid cell production occurs, and the circulating red cells represent an aged cohort of erythrocytes. At diagnosis, the band 4.1 of red cell membranes was nearly entirely in the a form, and as reticulocyte levels rose during recovery, the predominant form became $4.1 \mathrm{~b}$. After recovery, the $\mathrm{a} / \mathrm{b}$ ratio returned to normal. A transient period of moderate reticulocytosis and high levels of 4.1a could be detected in some cases, presumably marking the beginning of the recovery phase. These results support the proposal that the 4.1 band ratio is an internal marker of cell age in the human erythrocyte. (Pediatr Res 21: 275-278, 1987)
\end{abstract}

\section{Abbreviations}

TEC, transient erythroblastopenia of childhood PMSF, phenylmethylsulfonylfluoride

SDS-PAGE, sodium dodecyl sulfate polyacrylamide gel electrophoresis

RBC, red blood cell

DTT, dithiothreitol

TEC is a relatively uncommon childhood disorder characterized by temporary cessation of erythroid cell production, while leuckocyte and platelet production apparently remains normal $(1,2)$. Typically, the marrow recovers spontaneously, although supportive transfusions are occasionally required. Following recovery, these children have normal hematological findings. The causative agent has not yet been identified, although both humoral and cellular inhibitors of erythropoiesis have been shown to be present in these children (3). Classically, those children

Received June 18, 1986; accepted October 23, 1986.

Reprints Dr. Y. Ravindranath, Department of Pediatrics, Wayne State Medical School, 3901 Beaubien Blvd., Detroit, MI 48201.

Supported in part by the March of Dimes Grant 6-402, and NIH Grant AM33846 .

'Presented in part at the annual meeting of the Society of Pediatric Research, Washington, DC, 1983 (Pediatr Res 17:242a, 1983). who present with TEC are devoid of erythroid precursors in the marrow. Thus, this disease provides an experiment of nature useful in identifying the characteristics of aging red cells. The erythrocytes in the circulation of patients with TEC are aging cells, since they are not replenished during the period of marrow aplasia. In addition, it is reasonable to assume that the circulating cells are normal, since they were produced before the onset of the disease. We have taken advantage of this fact to demonstrate that the membrane skeleton protein, band $4.1 \mathrm{~b}$, is converted to 4.1a in aging human erythrocytes.

\section{METHODS}

Preparation of erythrocytes and ghosts. Cells from whole blood anticoagulated with heparin were washed once in $5 \mathrm{mM}$ Tris, $140 \mathrm{mM} \mathrm{NaCl}$, pH 7.4, containing $1 \mathrm{mM}$ EDTA. They were then passed over a microcellulose column (4) to remove white cells and washed in the same buffer with $20 \mu \mathrm{g} / \mathrm{ml}$ PMSF added to inhibit proteolysis. Ghosts were prepared by lysis and washing in low ionic strength Tris buffer $(5 \mathrm{mM}$ Tris, $7 \mathrm{mM} \mathrm{NaCl}, 1 \mathrm{mM}$ EDTA, $20 \mu \mathrm{g} / \mathrm{ml}$ PMSF, $\mathrm{pH}$ 7.4). Membranes were solubilized immediately prior to electrophoresis, by the addition of an equal volume of denaturing buffer containing $2.0 \%$ SDS, $20 \%$ sucrose, $2.0 \mathrm{mM}$ EDTA, $80 \mathrm{mM}$ DTT, and $20 \mathrm{mM}$ Tris, pH 8.0 , and immersion in a boiling water bath for $3 \mathrm{~min}$. Electrophoresis was performed on $4-12 \%$ gradients of acrylamide using the Laemmli Tris-glycine buffer system, $\mathrm{pH} 9.0$ (5), since this buffer system resolves the $a$ and $b$ forms of band 4.1. The relative proportions of various bands were quantitated by scanning Coomassie blue stained gels on a Zieneh densitometer.

Patient samples. Blood samples were obtained from patients with hemolytic anemias and TEC after informed consent.

\section{RESULTS}

TEC patients. Seven patients with TEC were studied, using SDS-gel electrophoresis. In the Laemmli gel system, protein band 4.1 splits into two polypeptides, $4.1 \mathrm{a}(83,000 \mathrm{Da})$ and $4.1 \mathrm{~b}$ $(81,000 \mathrm{Da})$. In the TEC patients, band $4.1 \mathrm{~b}$, the lower band of the 4.1 doublet, was absent or markedly reduced in the cells at diagnosis and in the immediate postdiagnosis period, when reticulocyte counts were zero (Fig. $1 A$, lane $B$ ). The relative proportions of the erythrocyte membrane proteins in these seven children with TEC at diagnosis are shown in Table 1, where the preponderance of $4.1 \mathrm{a}$ in these senescent cells is evident. During resolution of the disease, reticulocyte counts rise abruptly as normal red cell production recovers, and $4.1 \mathrm{~b}$ appears in the red cells (Fig. 1A, lane $C$ ). Two months after recovery, the red cell pattern is normal. The rise in $4.1 \mathrm{~b}$ in recovery is consistent with the proposal of Sauberman et al. (6) that high levels of $4.1 \mathrm{~b}$ is characteristic of young cells. Sauberman et al. (6) reached this 


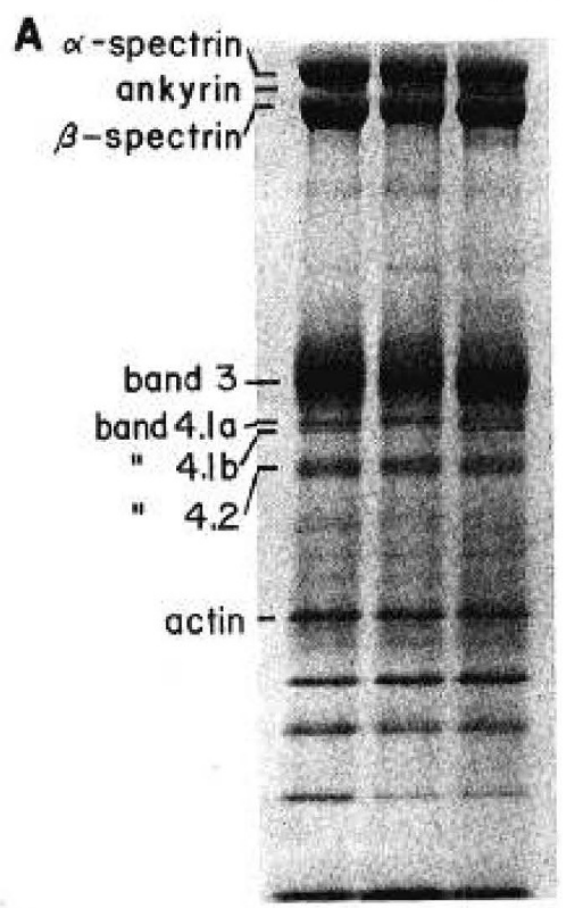

A B C

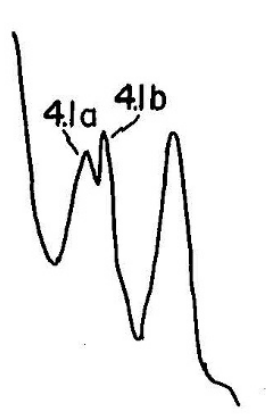

Control

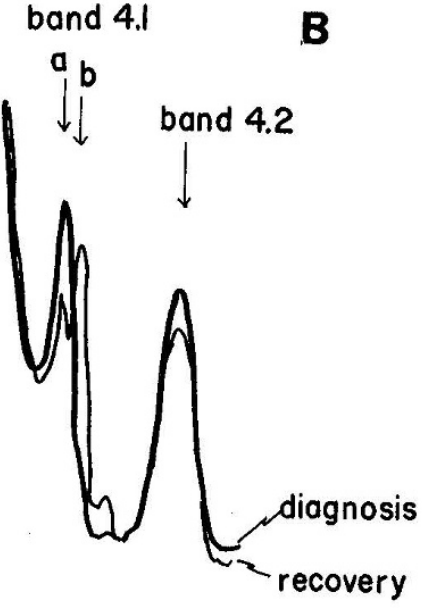

TEC

Fig. 1. $A$, SDS gel electrophoresis of erythrocyte membranes. (a) control; $(b, c)$ TEC patient $(b)$ at diagnosis, $(c)$ during recovery phase. $B$, densitometric traces of the 4.1 region of SDS gels. The change in the relative proportion of $4.1 \mathrm{a}(83 \mathrm{~K})$ and $\mathrm{b}(81 \mathrm{~K})$ is shown in a TEC patient at diagnosis and during the recovery phase. After recovery, band 4.1 in all the TEC patients resembled the control scan.

Table 1. Laemmli SDS-gels were scanned through the band 3 to band 4.2 regions with a Zieneh densitometer, and the relative amounts of band $4.1 \mathrm{a}$ and 4.16 were quantitated by automatic integration

\begin{tabular}{llc}
\hline Patient & $\begin{array}{c}4.1 \mathrm{a} / 4.1 \mathrm{~b} \text { ratio } \\
\text { at diagnosis }\end{array}$ & Reticulocytes (\%) \\
\hline $\mathrm{AB}$ & 3.5 & 1.2 \\
$\mathrm{NH}$ & 1.8 & $<1$ \\
$\mathrm{RD}$ & 2.5 & 0 \\
$\mathrm{BC}$ & 2.3 & $<0.1$ \\
$\mathrm{NS}$ & 5.0 & 3 \\
$\mathrm{BS}$ & 8.7 & $<0.1$ \\
$\mathrm{CD}$ & 5.0 & 0 \\
Controls & $1.02 \pm 0.07$ & \\
\hline
\end{tabular}

conclusion through an examination of reticulocyte-rich fractions from hemolytic anemias, which uniformly have high $4.1 \mathrm{~b}$ ratios. In the course of other investigations, we have identified about 40 children with hemolytic anemia of differing origins. In every case, we also found the red cells to be deficient in band 4.1a, verifying the results of Sauberman et al. (6). In several of these cases, the membranes were deficient in spectrin but the increased ratio of $4.1 \mathrm{~b}$ to $4.1 \mathrm{a}$ was always seen, independently of the amount of spectrin. Both the TEC and the hemolytic anemia data, therefore, support the identification of $4.1 \mathrm{~b}$ as a marker for reticulocytes or young erythrocytes.

Three of the patients recovered spontaneously without receiving transfusions, and in these children changes in the red cell membrane proteins could be followed during the recovery phase. Transfusions were necessary in the other four patients, eliminating any sequential study, but electrophoresis of RBC membranes obtained when they were hematologically normal showed a normal pattern.

In Figure 2, the reticulocyte level in all the samples we have examined is given as a function of $a-b / a+b$, where $a$ and $b$ are

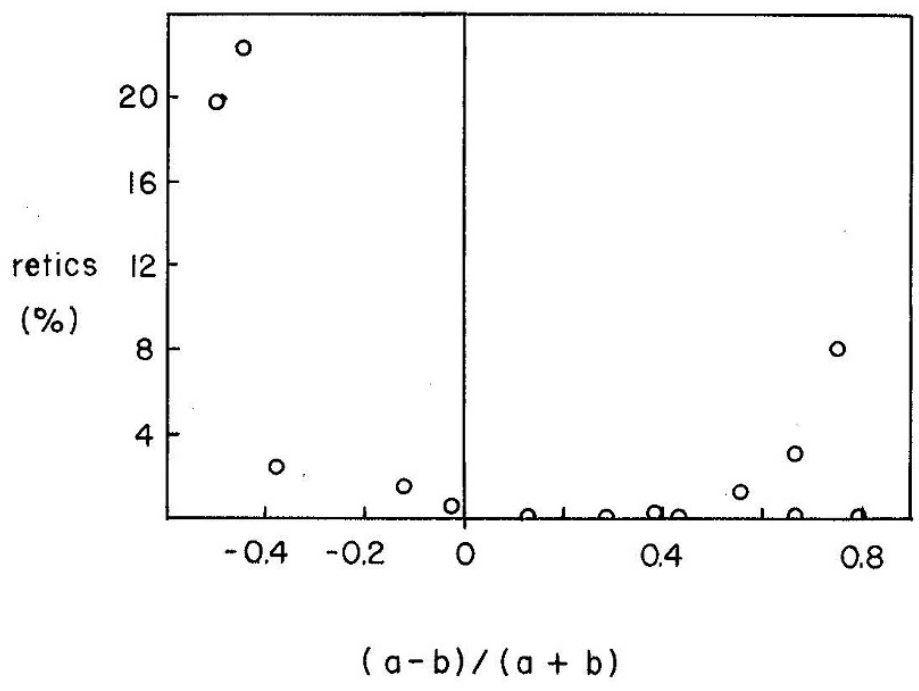

Fig. 2. Reticulocyte levels and the composition of band 4.1. The percentage of reticulocytes in all blood samples obtained from TEC patients is plotted as a function of $(\mathrm{a}-\mathrm{b}) /(\mathrm{a}+\mathrm{b})$, where $a$ is the integrated stain density of band $4.1 \mathrm{a}$ and $b$ is the integrated stain density of $5.1 \mathrm{~b}$.

the integrated peak densities under the $4.1 \mathrm{a}$ and $4.1 \mathrm{~b}$ peaks, respectively. This parameter has the advantages of normalizing the relative amounts of the polypeptides so that gels with different staining intensities can be compared, and giving equal weight to the amounts of bands $a$ and $b$. In this plot, negative values indicate more $4.1 \mathrm{~b}$ than a, and positive values indicate a preponderance of 4.1a. There are a number of striking features in the data. A high reticulocyte count is correlated with negative values of the parameter. This could have been predicted, since the reticulocyte-rich red cell populations obtained from hemolytic anemia patients are known to have high $4.1 \mathrm{~b}$ levels (6). Where 
reticulocyte levels are very low or zero, the parameter is positive, since, as expected from the SDS gels shown above, TEC patients at diagnosis show greater 4.1a than $4.1 \mathrm{~b}$ levels. The unexpected finding in Figure 2 is an association between moderately high reticulocyte levels and the highest values of the parameter, i.e. in those samples where the preponderance of 4.1a is greatest.

This paradoxical finding is clarified by an examination of the three cases in which we were able to obtain longitudinal data, permitting the evolution of the band 4.1 pattern to be followed over time (Fig. 3). In patient RD, the first sample was obtained when reticulocyte levels were zero and $4.1 \mathrm{a}>\mathrm{b}$. The second sample was obtained during recovery (reticulocytes high and $\mathrm{b}>\mathrm{a})$. The final sample was obtained from patient RD after recovery $(4.1 \mathrm{a}=4.1 \mathrm{~b})$. These data are in accord with the proposal that $4.1 \mathrm{a}$ is a marker for mature red cells. For patient CD, however, the timing of the samples within the cycle of disease and recovery was different. The first sample was obtained before recovery began. The second sample, however, was clearly obtained as the reticulocyte level rose, but before enough young cells entered the circulation to change the $a / b$ ratio of the red cell population. The association of high levels of $4.1 \mathrm{a}$ and moderate reticulocytosis is therefore characteristic of the earliest stage of recovery. This explains the presence of significant reticulocyte levels in populations of senescent red cells, at the right side of Figure 2.

\section{DISCUSSION}

The structural integrity of the red cell depends on a twodimensional network lining the cytoplasmic surface of the cell membrane (7). The major components of this network are spectrin, an elongated tetrameric molecule, linked to short filaments of actin. Protein 4.1 is a phosphorylated membrane protein that binds to spectrin (8) and promotes the association of spectrin and actin (9). Other observations strongly support a role for protein 4.1 in maintaining membrane integrity and red cell shape: deficiency of band 4.1 is associated in two kindreds with hemolytic elliptocytosis $(10,11)$; and defective spectrin-4.1 binding is associated with some cases of hereditary spherocytosis (12). Protein 4.1 appears as a single band on SDS gel electrophoresis of the red cell membrane proteins when the continuous buffer systems (13) are used. However, band 4.1 resolves into two components, $4.1 \mathrm{a}$ ( 83,000 daltons) and $4.1 \mathrm{~b}$ (81,000 daltons), in the discontinuous buffer system of King and Laemmli (5). They are closely related molecules, with nearly identical tryptic digestion patterns (14). The exact reasons for the difference in the migration of 4.1a and $\mathrm{b}$ on discontinuous SDS-PAGE are not known. Since band 4.1 a has a higher estimated molecular weight than band 4.1 b by approximately 2000 daltons, the posttransla-

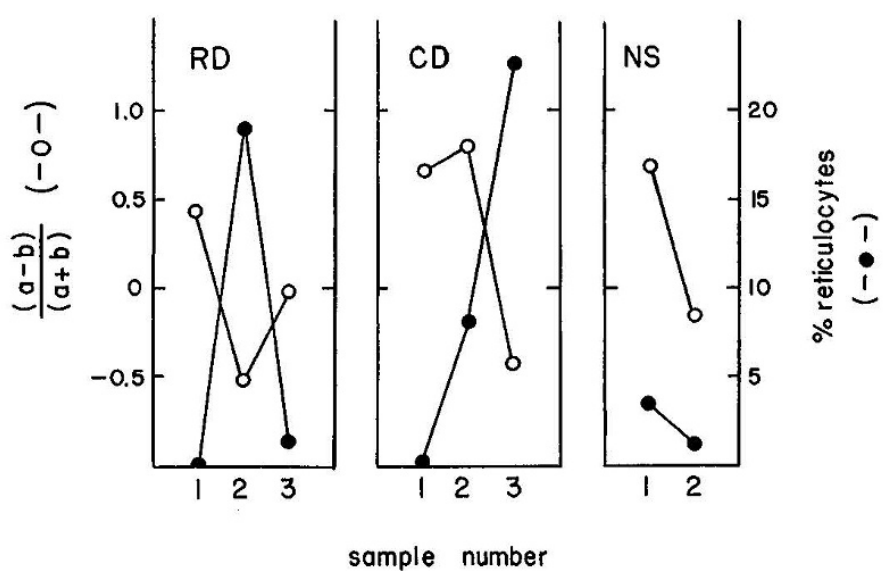

Fig. 3. Longitudinal data on three TEC patients. The percentage of reticulocytes and $(a-b) /(a+b)$ is presented. tional modification that occurs during cell aging apparently results in the addition of a small polypeptide. This is unlikely, however, given the restricted metabolic abilities of the mature red cell, and the differences in migration in discontinuous SDSPAGE is more likely due to a posttranslational modification leading to a charge difference or to intramolecular links.

In this study we present evidence that the relative proportions of band 4.1 $\mathrm{a}$ and $\mathrm{b}$ are age-dependent in the human erythrocyte. TEC is a unique disorder in which there is temporary suppression of erythroid differentiation (1-3). Thus, at the time of marrow red cell aplasia, the circulating erythrocytes represent primarily older red cells produced prior to marrow suppression, while during recovery the younger erythrocytes and reticulocytes predominate. This experiment of nature provides an opportunity to study the age-related changes in the relative proportion of band 4.1 $\mathrm{a}$ and $\mathrm{b}$ in senescent human erythrocytes. Sauberman et al. (6) have previously shown that 4.1a is deficient in red cells of patients with a variety of hemolytic anemias, and they suggested that younger red cells are deficient in 4.1a. We have verified this result, both with hemolytic anemia patients and in recovering TEC patients, whose red cells uniformly show very high levels of band $4.1 \mathrm{~b}$. The use of TEC erythrocytes during the period of marrow suppression has enabled us to make the additional observation that this ratio reverses in older erythrocytes, where most of the band 4.1 is in the "a" form. Morrison et al. (15) have provided evidence that the same phenomenon of protein conversion occurs in mice, using a hypertransfusion protocol to suppress erythropoesis.

Bands $4.1 \mathrm{a}$ and $\mathrm{b}$ have not been purified as distinct proteins and therefore it is not yet possible to determine whether the two proteins differ significantly with relation to their effect on the interaction of spectrin and actin. Recent data of Goodman et al. (14) suggest that both bind to spectrin heterodimers in solution. Therefore, at this stage, it is premature to speculate that any differences in the stability of membrane skeleton or the deformability of younger and older red cells could be explained solely on the basis of differences in the ratios of $4.1 \mathrm{a}$ and $\mathrm{b}$.

Beutler and Hartman (16) recently determined enzyme levels in TEC patients and noted that most levels did not decline with age. This brings into question a commonly used criterion (17) for aged red cells, the loss of certain catalytic activities. Our studies show that the time-dependent conversion of band $4.1 \mathrm{~b}$ to $4.1 \mathrm{a}$, predicted earlier by Sauberman et al. (6), is a valid marker for cell senescence and may be a more valid criterion than the level of enzymatic activity. In addition, longitudinal studies of three children suggest that in TEC there is a transient stage of moderate reticulocytosis with a high proportion of $4.1 \mathrm{a}$, characterizing the initial stages of recovery. The relative proportions of $4.1 \mathrm{a}$ and $\mathrm{b}$ could therefore be used to confirm the diagnosis of TEC in patients first seen in the early stages of recovery.

\section{REFERENCES}

1. Gerrits GPJM, van Oostrom CG, de Vaan GAM, Bakkeren JAJM 1984 Transient erythroblastopenia of childhood: a review of 22 cases. Eur J Pediatr $142: 266-270$

2. Alter BP 1980 Childhood red cell aplasia. Am J Pediatr Hemol Oncol 2:121139

3. Freedman MH, Saunders EF 1983 Transient erythroblastopenia of childhood: varied pathogenesis. Am J Hematol 14:247-254

4. Beutler E, West C 1976 The removal of leukocytes and platelets from whole blood. J Lab Clin Med 88:328-333

5. King J, Laemmli U 1971 Polypeptides of the tail fibres of bacteriophage T4. J Mol Biol 62:465-468

6. Sauberman N, Fortier NL, Fairbanks GF, O'Connor RJ, Snyder LM 1979 Red cell membrane in hemolytic disease. Studies on variables affecting electrophoretic analysis. Biochim Biophys Acta 556:292-313

7. Branton D, Cohen CM, Tyler J 1981 Interaction of cytoskeletal proteins on the human erythrocyte membrane. Cell 24:24-32

8. Tyler JM, Hargreaves WR, Branton D 1980 Purification of two spectrinbinding proteins: Biochemical and electron microscopic evidence for sitespecific reassociation between spectrin and bands 2.1 and 4.1 Proc Natl Acad Sci USA 76:5192-5296

9. Ungewickell E, Bennett PM, Calvert R, Ohanian V, Gratzer WB 1979 In vitro 
formation of a complex between cytoskeletal proteins of the human erythrocyte. Nature 280:811-814

10. Feo CS, Fischer S, Piau JP, Grange MJ, Tchernia G 1980 Primiere observation de l'absence d'une proteine de la membrane erythrocytaire (band 4.1) dan un cas d'anemie elliptocytaire familiale. Nouv Rev Fran Hematol 22:315325

11. Mueller TJ, William J, Wang W, Morrison M 1981 Cytoskeletal alterations in hereditary elliptocytosis. Blood $58: 47 \mathrm{a}$

12. Goodman SR, Shiffer KA, Casoria LA, Eyster ME 1982 Identification of the molecular defect in the erythrocyte membrane skeleton of some kindreds with hereditary spherocytosis. Blood 60:772-784

13. Fairbanks G, Steck TL Wallach DFH 1971 Electrophoretic analysis of the major polypeptides of the human erythrocyte membrane. Biochemistry
$10: 2606-2617$

14. Goodman SR, Yu J, Whitfield CF, Culp EN, Posnak EJ 1982 Erythrocyte membrane skeletal protein bands $4.1 \mathrm{a}$ and $4.1 \mathrm{~b}$ are sequence-related phosphoproteins. J Biol Chem 257:4564-4569

15. Morrison M, Jackson CW, Mueller TJ, Huang T, Dockter ME, Walker WS, Singer JA, Edwards HH 1983 Does red cell density correlate with red cell age? Biomed Biochim Acta 42:S107-SH11

16. Beutler E, Hartman G 1985 Age-related red cell enzymes in children with transient erythroblastopenia of childhood and with hemolytic anemia. Pediatr Res 19:44-47

17. Seaman C, Wyss S, Piomelli S 1980 The decline in energetic metabolism with aging of the erythrocyte and its relationship to cell death. Am J Hematol $3: 31-42$ 